\title{
Bottle brush Callistemon lanceolatus DC (Myrtaceae) nectar: amount, type of nectar sugars and honeybee foraging
}

\author{
JK Gupta 1, J Kumar 2 \\ ${ }^{1}$ Department of Entomology, Dr YS Parmar University of Horticulture \\ and Forestry Nauni, Solan - 173230 ; \\ 2 RRS, HPKV, Bajaura, Kullu, (HP) India
}

(Received 28 September 1992 ; accepted 5 May 1993)

\begin{abstract}
Summary - The maximum amount of nectar sugars in the flowers of bottle brush, Callistemon lanceolatus, protected from nectarivores was $6.044 \mathrm{mg} /$ flower $72 \mathrm{~h}$ after flower opening, whereas the $24-\mathrm{h}$ sugar value was only $0.44 \mathrm{mg}$. Apis mellifera harvested $\approx 90 \%$ of the sugar produced by the flowers. The concentration of solutes in the nectar ranged between 25 and $40 \%$. Only fructose and glucose were found to be present in the nectar. A mellifera visited 9.5 flowers $/ \mathrm{min}$ to collect nectar.
\end{abstract}

Apis mellifera / Callistemon lanceolatus / nectar secretion / foraging behaviour

\section{INTRODUCTION}

Bottle brush, Callistemon lanceolatus DC (Myrtaceae), is native to Australia. In India it is cultivated as an ornamental plant. The bright-scarlet bottle brush inflorescence of this tree is most ornamental, and there is a resulting rapid expansion of roadside plantations of this plant. Although it has invariably been included in the honeybee floral calender (Srawan and Sohi 1985; Garg 1989), information on its nectar characteristics and attractiveness to honeybees and other insects is lacking. The present study was undertaken to quantify the nectar sugars produced per flower, and to determine the period of nectar secretion and the proportion of various foraging nectarivores.

\section{MATERIALS AND METHODS}

The observations were carried out during AprilMay at Nauni, Solan, India (1 $400 \mathrm{~m}$ above sea level), near an apiary with 20 Apis mellifera and $2 A$ cerana indica colonies. The amount of sugar present in $C$ lanceolatus flowers of different age was determined by enclosing floral buds in nylon cages on 3 different trees. The sampling was made at $24-h$ intervals. At each sampling 
time, 10 flowers were individually rinsed for $45 \mathrm{~min}$ in $5 \mathrm{ml}$ distilled water in a capped vial. After removing the flower, the sugar in the rinsate was analysed (Roberts, 1979). A parallel set of floral buds was left open and flowers were sampled at 0 (freshly opened flowers), 24, 48, 72,96 and $120 \mathrm{~h}$ and the dry sugar content determined. Microcapillary tubes $(5 \mu \mathrm{l})$ were used to remove nectar from the caged flowers and the sugar concentration was recorded with a hand refractometer (range $0-50 \%$ Bellingham and Stanley Ltd, Tunbridge Wells UK). The sugar concentration was determined in 150 flowers (50 flowers each from 3 different trees). Nectar sugars were identified by descending paper chromatography using butanol, benzene, pyridine and water (5:1:3:3) as solvent and aniline phthalate as developer (Zweig and Whitakar, 1971).

The counts of different insect foragers were made on 2 inflorescence/ 5 min, each in 3 trees, during each observation period. These counts were continued for 3 sunny days, and the average values represented insect activity during different day-time hours.

The data were analysed via factorial randomised block design (Panse and Sukhatme, 1978).

\section{RESULTS AND DISCUSSION}

At the experimental site $C$ lanceolatus mainly bloomed during April-May, with a number of other minor flushes during the year. Each inflorescence contained on average 58 flowers (ranging between 45-71 flowers, $n=100$ ).

\section{Nectar solute concentration}

The solute concentration in the nectar varied between $25-40 \%$ in flowers of different ages $(25-30 \%$ in $24-\mathrm{h}, 25-32 \%$ in $48-\mathrm{h}$ and $38-40 \%$ in $72-h$-old flowers); based on forager honey sac contents, Srawan and Sohi (1985) reported the nectar concentration of $C$ lanceolatus to be $12 \%$.

\section{Nectar secretion rate}

The amount of nectar sugars accumulated varied in the flowers protected from insect visits (table I). The nectar sugar content in the freshly opened flowers amounted to $0.173 \mathrm{mg} /$ flower. The $C$ lanceolatus $24-\mathrm{h}$ sugar value (the amount of sugar accumulated within $24 \mathrm{~h}$ of flower opening) was $0.44 \mathrm{mg}$. This value is generally used to express attractiveness of a nectar source to nectarivores (Crane, 1975). C lanceolatus nectar was found to have increasing amounts of sugar until $72 \mathrm{~h}$ after flower opening. Therefore, the $24-\mathrm{h}$ value may underestimate the total nectar potential. Hence it is suggested that instead of the 24-h sugar value, the maximum amount of sugar accumulated in a flower should be considered as an index of bee flora attractiveness. In 96-h-old flowers the amount of sugar dropped to $4.8 \mathrm{mg} / \mathrm{flower}$. This indicates a resorption of $\approx 19 \%$ of the secreted nectar. This amount is low compared to that observed in flowers of certain other

Table I. Nectar sugar content (mg/flower) in caged and unprotected flowers of Callistemon lanceolatus of different ages.

\section{Flower age Unprotected Caged flowers flowers}

$\begin{array}{lll}\text { Freshly opened } & 0.173 & 0.173 \\ 24 \mathrm{~h} & 0.254 & 0.44 \\ 48 \mathrm{~h} & 0.18 & 4.822 \\ 72 \mathrm{~h} & 0.231 & 6.044 \\ 96 \mathrm{~h} & 0.261 & 4.8 \\ 120 \mathrm{~h} & 0.148 & 5.2 \\ & & \\ \text { Mean } & 0.208 & 3.58\end{array}$

$\mathrm{CD}(P=0.05)$; Caged/unprotected $=0.32$; interaction flower age $\times$ caged/unprotected $=$ significant; any pair of combinations $=0.78$. 
plant species (varying between 42-96\%; Gupta et al, 1984, 1986; Mishra et al, 1985; Reddy and Gupta, 1987). C lanceolatus flowers started to wither after $120 \mathrm{~h}$ but still contained $5.2 \mathrm{mg}$ sugar/flower at that time.

Flowers foraged by nectarivores had sugar amounts that varied between 0.148 to $0.261 \mathrm{mg} /$ flower (non-significant differences). Thus honeybees (which were the main foragers) appeared to harvest $>90 \%$ of the secreted nectar. The qualitative analysis revealed that $C$ lanceolatus nectar contained only fructose and glucose.

A mellifera activity remained high throughout the day, constituting $87 \%$ of the insect visits (table II). A c indica showed no activity; this was probably due to the presence of only 2 colonies, as compared to 20 A mellifera colonies. However, at a distance of $\approx 2 \mathrm{~km}, A c$ indica activity was very high on $C$ lanceolatus flowers. At this distance, the feral population constituted the source of $A c$ indica. Honeybees show typical foraging behaviour on $C$ lanceolatus flowers. They land on the lower flowers and then gradually climb up the flowers while collecting nectar. A mellifera foraging rate was 9.5 flowers $/ \mathrm{min}$. Each flower was observed to be foraged by as many as 10 bees during a $1-\mathrm{h}$ period. Honeybee foraging rate depends upon foraging behaviour and the floral structure of the plant concerned. A mellifera foraging rates on some other plants vary from 3.8 to 9.1 flowers/ min (Free, 1970). In addition to honeybees, Diptera were found to be occasional visitors but were only observed during the counts at 10:00 h.

Résumé - Étude quantitative et qualitative des sucres du nectar de Callistemon lanceolatus DC (Myrtaceae) et comportement de butinage des abeilles. L'étude a été faite à Solan (Himachal Pradesh, Inde, $1400 \mathrm{~m}$ d'altitude) à proximité d'un rucher comportant 20 colonies d'Apis mellifera et 2 colonies d'Apis cerana indica dans le but de déterminer la quantité de nectar sécrétée, la durée de la sécrétion nectarifère, la quantité de sucres prélevée par les nectarivores, la concentration en sucres et le type de sucres du nectar de Callistemon lanceolatus, plante ornemen-

Table II. Number of insect visitors per 5 min per 2 inflorescences of Callistemon lanceolatus during different day-time hours.

\begin{tabular}{|c|c|c|c|c|c|}
\hline \multirow[t]{2}{*}{ Insect visitor } & \multicolumn{3}{|c|}{ Time of day } & & \multirow[t]{2}{*}{ Mean } \\
\hline & $10: 00$ & $12: 00$ & $14: 00$ & $16: 00$ & \\
\hline A mellifera & $\begin{array}{c}8.3 \\
(3.03)^{\star}\end{array}$ & $\begin{array}{c}8.7 \\
(3.25)\end{array}$ & $\begin{array}{c}7.5 \\
(2.93)\end{array}$ & $\begin{array}{c}7.7 \\
(2.99)\end{array}$ & $\begin{array}{r}8.05 \\
(3.05)\end{array}$ \\
\hline A dorsata & $\begin{array}{c}1.6 \\
(1.55)\end{array}$ & $\begin{array}{c}1.0 \\
(1.52)\end{array}$ & $\begin{array}{c}0.5 \\
(1.27)\end{array}$ & $\begin{array}{c}0.5 \\
(1.27)\end{array}$ & $\begin{array}{c}0.9 \\
(1.4)\end{array}$ \\
\hline Diptera & $\begin{array}{c}0.6 \\
(1.24)\end{array}$ & $\begin{array}{c}0.0 \\
(1.0)\end{array}$ & $\begin{array}{c}0.0 \\
(1.0)\end{array}$ & $\begin{array}{c}0.0 \\
(1.0)\end{array}$ & $\begin{array}{r}0.15 \\
(1.06)\end{array}$ \\
\hline Mean & $\begin{array}{c}3.5 \\
(1.94)\end{array}$ & $\begin{array}{r}3.23 \\
(1.92)\end{array}$ & $\begin{array}{r}2.67 \\
(1.73)\end{array}$ & $\begin{array}{r}2.73 \\
(1.75)\end{array}$ & \\
\hline
\end{tabular}

* Figures in parentheses indicate $\sqrt{n+1}$ transformation; ${ }^{C D}(P=0.05)$; for insect foragers $=0.39$; for day-time hours = non-significant; interaction (insect $x$ day-time hours) $=$ significant; any pair of combinations $=0.78$. 
tale largement répandue. La quantité de sucres présente dans les fleurs a été déterminée en rinçant les fleurs à l'eau distillée et en analysant l'eau de rinçage (méthode de Roberts, 1979). On a prélevé le nectar avec des microcapillaires $(5 \mu \mathrm{l})$ et analysé sa concentration à l'aide d'un réfractomètre à main (Bellingham et Stanley, Angleterre ; domaine de mesure : 0-50\%). L'analyse qualitative des sucres du nectar a été faite par chromatographie sur papier. L'activité des insectes butineurs a été enregistrée sur 2 inflorescences pendant 5 $\min$ à $10,12,14$ et $16 \mathrm{~h}$. La quantité de sucres sécrétée en $24 \mathrm{~h}$ par $C$ lanceolatus a été de $0,44 \mathrm{mg}$ (tableau I), mais la quantité maximum a été trouvée dans les fleurs âgées de 72 h $(6,044$ mg/fleur). Ensuite la quantité redescendait dans les fleurs âgées de $96 \mathrm{~h}$, indiquant la résorption d'environ $19 \%$ du nectar sécrété. Les fleurs butinées par les nectarivores contenaient de 0,148 à $0,261 \mathrm{mg}$ de sucre/fleur. L'analyse qualitative a montré que le nectar avait une forte teneur en hexoses puisqu'il ne comportait que du fructose et du glucose. A mellifera représentait $87 \%$ des insectes qui visitaient la plante (tableau II). Le taux de butinage de l'abeille domestique était de 9,5 fleurs/min.

\section{Apis mellifera / Callistemon lanceola- tus / nectar / glucide / butinage}

\footnotetext{
Zusammenfassung - Nektar des “Bottle brush", Callistemon lanceolatus DC (Myrtaceae): Menge, Art der Nektarzucker und Sammelverhalten der Bienen. Diese Untersuchungen wurden in Solan (1 $400 \mathrm{~m}$ üdM), HP, Indien, in der Nähe eines Bienenstandes mit 20 Völkern von Apis mellifera und einigen Völkern von A cerana indica unternommen, um bei dem als "Bottle brush" (Callistemon lanceolatus) bezeichneten Strauch die Menge des von den Blüten erzeugten Nektars, die
}

Menge der von Besuchern gesammelten Nektarzucker, die Nektarkonzentration und die Art der produzierten Zucker zu bestimmen.

Die Menge des in den Blüten vorhandenen Zuckers wurde nach der Methode von Roberts (1979) mit einem "Spectronic 20" bestimmt, wobei nach Spülung der Blüten in destilliertem Wasser die Spülflüssigkeit analysiert wurde. Zur Bestimmung der Zuckerkonzentration wurde Nektar in Mikrokapillaren $(5 \mu \mathrm{l})$ entnommen und die Konzentration in einem Handrefraktometer (Bellingham and Stanley, England; Meßbereich $0-50 \%$ ) bestimmt. Die Nektarzucker wurden papierchromatographisch bestimmt. Das Verhalten von Nektarsammlern wurde jeweils für $5 \mathrm{~min}$ an zwei Blütenständen um $10.00,12.00,14.00$ und $16.00 \mathrm{~h}$ registriert.

Der 24-h Zuckerwert von $C$ lanceolatus betrug $0.44 \mathrm{mg}$ (Tabelle 1), aber die größte Zuckermenge wurde in $72 \mathrm{~h}$ alten Blüten gefunden ( $6.044 \mathrm{mg} /$ Blüte); danach fiel die Menge in $96 \mathrm{~h}$ alten Blüten $\mathrm{ab}$, was auf eine Resorption von etwa $19 \%$ des abgesonderten Nektars hinweist. Von Sammlern besuchte Blüten enthielten $0.148-$ $0.261 \mathrm{mg}$ Zucker/Blüte. Die qualitative Nektaranalyse ergab einen hohen Gehalt an Hexosen, bestehend ausschließlich aus Fruktose und Glukose. Bei den blütenbesuchenden Insekten (Tabelle 2) stellte $A$ mellifera $87 \%$. Die Sammelfrequenz von $A$ mellifera betrug 9.5 Blüten/min.

\section{Callistemon lanceolatus / Nektar- zucker / Sammelverhalten}

\section{REFERENCES}

Crane E (1975) Honey: A Comprehensive Survey, Heinenmann, London

Free JB (1970) Insect Pollination of Crops. Academic Press, London 
Garg R (1989) Bee flora of Paonta valley. Ind Bee J 51, 113-114

Gupta JK, Kumar J, Mishra RC (1984) Nectar sugar production and honeybee foraging activity in different cultivars of cauliflower, Brassica oleracea var botrytis. Ind Bee J 46, 21-22

Gupta JK, Thakur RK, Kumar J (1986) Nectar of wild olive, Elaegnus umbellata Thunb and foraging intensity of different insect visitors. Ind Bee J 48, 40-42

Gupta JK, Thakur RK (1987) Nectar sugar production and flower of the bramble, Rubus ellipticus Smith (Rosaceae). Apidologie 18, 223-230

Mishra RC, Gupta JK, Kumar J (1985) Nectar sugar production in peach, Prunus persica $L$. Ind Bee J 47, 37-39
Panse VG, Sukhatme PV (1978) Statistical Methods for Agricultural Workers. ICAR, New Dehli

Reddy MCM, Gupta JK (1987) Wild cherry, Prunus puddum Roxb. A honey plant. In: Social Forestry for Rural Development (Khosla PK, Kohli RC, eds) ISTS, Solan, India

Roberts RB (1979) Spectrophotometric analysis of sugar produced by plants and harvested by insects. J Apic Res 18, 191-195

Srawan BS, Sohi BS (1985) Phytosociological studies on Apis mellifera and $A$ cerana indica in Punjab, India. Ind Bee J 47, 15-20

Zweig G, Whitaker JR (1971) Paper Chromatography and Electrophoresis. volume II, New York 